\title{
HYMNÉ À LA BEAUTÉ KARYA CHARLES BAUDELAIRE: KAJIAN SEMIOTIKA PUISI RIFFATERRE
}

\author{
Sunahrowi dan Marita Restu N. \\ Program Studi Sastra Perancis, Universitas Negeri Semarang \\ Kampus FBS Kampus Sekaran Gunung Pati, Semarang, Jawa Tengah \\ surel: sunahrowi@mail.unnes.ac.id
}

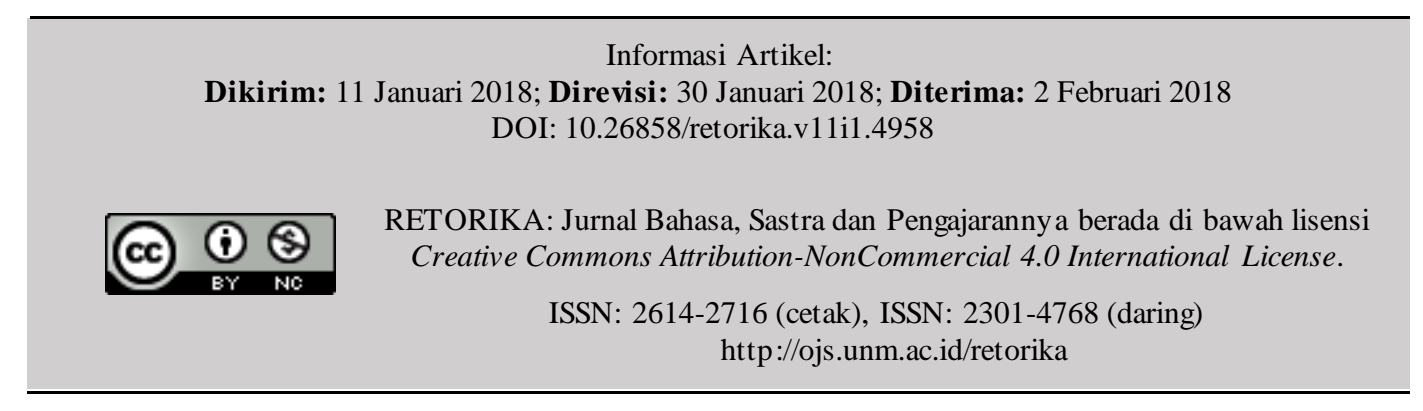

\begin{abstract}
Hymné à la Beauté The work of Charles Baudelaire: The Semiotics Review of Riffaterre Poems. This study aims to reveal the hidden meaning of Hymne à la Beauté poem by using semiotic method. The method is designed with qualitative research descriptive analys is. The data are sourced from the work of Charles Baudelaire in the anthology of poetry Les fleurs du Mal. Data analysis was done by analytical descriptive method. The results show that the Hymne à la Beauté poem contains Baudelaire love strands to Jeanne Duval, which is represented through various expressions of poetry and expressionlessness. This poem shows the admiration of a man to a woman and also the despair of love.
\end{abstract}

\begin{abstract}
Abstrak. Hymné à la Beauté Karya Charles Baudelaire: Kajian Semiotika Puisi Riffaterre. Penelitian ini bertujuan mengungkap makna tersembunyi dalam puisi Hymne à la Beauté dengan menggunakan metode semiotik. Metode didesain dengan penelitian kualitatif deskriptif analisis. Data bersumber dari karya Charles Baudelaire dalam antologi puisi Les fleurs $d u$ Mal. Analisis data dilakukan dengan metode deskriptif analitis. Hasil penelitian menunjukkan bahwa puisi Hymne à la Beauté berisi untaian cinta Baudelaire kepada Jeanne Duval yang direpresentasikan melalui berbagai macam ekspresi puisi dan ketidaklangsungan ekspresi. Puisi ini memperlihatkan kekaguman seorang lelaki kepada seorang perempuan dan juga rasa putus asa karena cinta.
\end{abstract}

Kata kunci: puisi, cinta, putus asa, dan semiotik 
Puisi adalah suatu bentuk dalam karya sastra yang berasal dari hasil suatu perasaan yang diungkapankan oleh penyair dengan bahasa yang menggunakan irama, rima, matra, bait dan penyusunan lirik yang berisi makna. Puisi juga berisi ungkapan perasaan dan pikiran dari penyair yang menggunakan imajinasinya. Sepanjang zaman, puisi selalu mengalami perubahan dan perkembangan. Hal ini sesuai hakikat karya seni yang selalu menimbulkan ketegangan antara konvensi dan pembaharuan atau inovasi (Teeuw, 1980:12). Puisi selalu mengalami perubahan menyesuaikan dengan evolusi selera dan perubahan konsep estetiknya (Riffaterre, 1978:1). Dari segi penulisan, puisi adalah karya sastra dengan bahasa yang dipadatkan, dipersingkat dan diberi irama dengan bunyi yang padu dan pemilihan kata-kata kias atau imajinatif. Dari definisi di atas tampak jelas bawa pemilihan atau penggunaan kata-kata dalam puisi bukan merupakan kata-kata yang biasa kita gunakan dalam percakapan sehari-hari. Dalam puisi menggunakan kata yang memiliki kekuatan dalam pengucapannya dan juga makna yang luas.

Puisi sebagai salah sebuah karya seni sastra dapat dikaji dari bermacam-macam aspeknya. Puisi dapat dikaji struktur dan unsur-unsurnya, mengingat bahwa puisi adalah struktur yang tersususun dari bermacam-macam unsur dan sarana-sarana kepuitisan. Puisi dapat pula dikaji jenis atau ragamnya, mengingat bahwa ada beragam-ragam puisi. Begitu juga, puisi dapat dikaji dari sudut kesejarahannya, mengingat bahwa sepanjang sejarahnya, dari waktu ke waktu puisi selalu ditulis dan selalu dibaca. Sepanjang zaman puisi selalu mengalami perubahan dan perkembangan.

Puisi sebagai salah satu karya sastra dapat dianalisis dari bermacam-macam aspeknya. Analisis menggunakan pendekatan semiotik dengan tujuan memahami makna yang terkandung dalam puisi. Menganalisis puisi adalah usaha menangkap dan memberi makna pada teks puisi. Sastra biasa diartikan sebagai teks dengan bahasa yang estetik dan isi yang baik. Bahasa yang estetik artinya bisa menimbulkan kesan dan menghibur pembacanya. Isi yang baik artinya bermanfaat yang berarti mengandung nilai moral. Analisis puisi dengan pendekatan semiotik bertujuan memahami makna yang terkandung dalam puisi. Menganalisis puisi adalah usaha menangkap dan memberi makna pada teks puisi. Sastra biasa diartikan sebagai teks dengan bahasa yang estetik dan isi yang baik. Bahasa yang estetik artinya bisa menimbulkan kesan dan menghibur pembacanya. Isi yang baik artinya bermanfaat yang berarti mengandung nilai moral.

Riffaterre (1978) mengemukakan bahwa ada empat hal yang harus diperhatikan dalam memahami dan memaknai sebuah puisi. Keempat hal tersebut adalah (1) ketidaklangsungan ekspresi, (2) pembacaan heuristik dan retroaktif/hermeneutik, (3) matriks atau kata kunci (key word), model, dan varian, (4) hipogram (berkenaan dengan prinsip intertekstualitas). Menurut Riffaterre puisi selalu berubah karena evolusi selera dan konsep estetik yang selalu berubah dari periode ke periode. Ia menganggap bahwa puisi adalah sebagai salah satu wujud aktivitas bahasa. Puisi berbicara mengenai sesuatu hal dengan maksud yang lain. Artinya, puisi berbicara secara tidak langsung sehingga bahasa yang digunakan pun berbeda dari bahasa sehari-hari. Jadi, ketidaklangsungan ekspresi itu merupakan konvensi sastra pada umumnya. Karya sastra itu merupakan ekspresi yang tidak langsung, yaitu menyatakan pikiran atau gagasan secara tidak langsung, tetapi dengan cara lain. Ketidaklangsungan ekspresi itu mencakup tiga hal, yaitu pergeseran makna (displacing of meaning), penyimpangan makna (distorting of meaning), dan penciptaan makna (creating of meaning).

Aktivitas pemaknaan secara semiotik dilakukan melalui dua tahap pembacaan, yakni pembacaan heuristik dan pembacaan hermeneutik. Pembacaan heuristik adalah pembacaan yang didasarkan pada konvensi bahasa, yakni menurut sistem semiotik tingkat pertama. Pembacaan heuristik ditujukan untuk menemukan arti bahasanya. Pembacaan heuristik dalam hal ini adalah pembacaan tata bahasa ceritanya, yaitu pembacaan dari awal sampai akhir cerita secara berurutan. Pembacaan hermeneutik adalah pembacaan yang didasarkan pada konvensi sastra, yakni menurut sistem semiotik tingkat kedua. Pembacaan heuristik dan hermeneutik yang dilakukan untuk menemukan petanda atau makna karya sastra.

Penelitian-penelitian dengan menggunakan objek formal teori semiotika Rifaterre sudah sering dilakukan oleh para peneliti, mahasiswa, dan kritikus sastra. Penelitian terbaru dengan objek formal teori ini dilakukan oleh Lukmana (2017) dengan judul La Religiosite et l'Obsession dans l'Anthologie de la Poesie les Fleurs du Mal Travail de Charles Baudelaire: l'Etude de la Semiotique de Riffaterre. Penelitian ini berusaha 
mengungkapkan hal-hal yang berkaitan dengan religiositas dan obsesi yang ada pada puisi karya Baudelaire ini. Berdasarkan hasil analisis disimpulkan bahwa ada relasi strategis tentang tema dan hal-hal yang berkaitan dengan kitab suci (alkitab). Penelitian lainnya dilakukan oleh Matalu, Wibowo, dan Sunahrowi (2017) dengan judul Les Cinq Poèmes de Charles Baudelaire Choisies de l'Anthologie "les Fleurs du Mal": Une Étude Selon la Perspective Hermèneutique Phénoménologique de Paul Ricour. Penelitian ini banyak menyoroti hal-hal yang berkaitan dengan kemuraman dan kesedihan. Meskipun objek material sama dengan penelitian sebelumnya di atas, namun fokus kajian dan tujuan penelitian ini berbeda. Penelitian ini memilih menggunakan objek formal hermeneutika Ricoeur.

Pemilihan puisi Hymne à la Beauté karya Charles Baudelaire karena puisi ini merupakan ungkapan untuk Jeanne Duval, wanita yang sangat dicintai Baudelaire. Penggambaran Baudelaire atas ungkapan cintanya kepada Jeanne sangat tercermin dari puisi ini. Bait demi bait yang ditata dengan diksi yang menarik dan tajam menunjukkan rasa cintanya yang begitu dalam.

\section{METODE}

Objek material dalam analisis ini adalah puisi berjudul Hymne à la Beauté karya Charles Baudelaire dari antologi puisi Les fleurs du Mal. Objek formal dalam penelitian ini adalah teori semiotika puisi dari Michael Riffaterre, berkaitan dengan pembacaan heuristik dan hermeneutik. Metode yang digunakan untuk analisis dan penyajian analisisnya adalah metode deskriptif analitis. Whitney (1960:160) metode deskriptif adalah pencarian fakta dengan interpretasi yang tepat. Sugiyono (2005:21) menyatakan bahwa metode deskriptif adalah suatu metode yang digunakan untuk menggambarkan atau menganalisis suatu hasil penelitian tetapi tidak digunakan untuk membuat kesimpulan yang lebih luas.

\section{HASIL DAN PEMBAHASAN}

\section{Ketidaklangs ungan Makna Puisi}

Bentuk ketidaklangsungan makna puisi yang terdapat dalam puisi Hymne à la Beauté yang ditemukan dalam penelitian ini terdiri atas (1) pergeseran makna, (2) penyimpangan makna, dan (3) penciptaan makna. Uraian setiap temuan hasil penelitian tersebut dipaparkan sebagai berikut.

\section{Pergeseran Makna}

Pergeseran makna terjadi apabila suatu tanda mengalami perubahan dari satu arti ke arti yang lain, ketika suatu kata mewakili kata yang lain. Penyebab terjadinya pergeseran makna adalah penggunaan bahasa kiasan, seperti metafora dan metonimi. Hal itu bisa dilihat dari baris (4): Et l'on peut pour cela te comparer au vin (orang bisa membandingkannya pada anggur). Kata anggur pada baris tersebut mengandung makna bahwa sesuatu yang terkadang digambarkan dengan anggur identik dengan sesuatu yang penuh nafsu dan gairah. Refleksi dari penggambaran kecantikan yang terkadang menjadi baik atau buruk.

Pada baris 6: Tu répands des parfums comme un soir orageux (Kau semerbakkan parfum seperti malam yang penuh badai). Baris tersebut terkandung makna yang menunjukkan bagaimana menariknya kecantikan yang begitu dipuja bahkan hingga direpresentasikan sebagai bau yang semerbak, seperti badai yang menerjang di malam hari. Baris 10: Le Destin charmé suit tes jupons comme un chien (Takdir terpesona mengikuti rokmu seperti anjing). Kata anjing dalam baris ini mengandung makna bahwa sangat terpesonanya dengan kecantikan itu sehingga sampai pesona yang diperlihatkan membuat tertunduk dan menurut bagai anjing dengan pemiliknya.

Pada baris 13 Tu marches sur des morts, Beauté, dont tu te moques (Kau berjalan diatas kematian, kecantikan, kau tak peduli) dan De tes bijoux l'Horreur n'est pas le moins charmant (Dari perhiasanmu, menjijikan, bukanlah yang paling bersinar). Bagian ini mengandung makna bahwa kecantikan yang membuat setiap mata terpana justru membuatnya seperti dalam bayang kematian dan dari beragam hal yang ditampilkan sebenarnya bukanlah sesuatu yang menawan. Pada baris 15 Et le Meurtre, parmi tes plus chères breloques (Dan pembunuhan, diantara hiasan-hiasan arlogimu yang sangat mahal) dan baris 16 Sur ton ventre orgueilleux danse amoureusement (di atas perutmu yang angkuh menari penuh kasih sayang). Bagian ini menggambarkan pemuja kecantikan yang menganggap semua darinya adalah sebuah keindahan dan ke- 
senangan. Penuh kasih sayang disini berarti setiap dari apa yang ditunjukkan merupakan sebuah kepalsuan dari sebuah keindahan.

Representasi kecantikan yang mempesona juga ditampilkan dengan penampilannya yang mengerikan. Puisi tersebut membuat hubungan antara kecantikan dan sesuatu mengerikan, seperti di baris 22 Ô Beauté! monstre énorme, effrayant, ingénu! (Ô kecantikan! Raksasa besar, mengerikan, naif!). Puisi tersebut ditulis dengan frasa yang ditampilkan dari kekaguman dan antusiasme penyair untuk keindahan dari kecantikan itu sendiri. Demikian pula, puisi tersebut menggunakan kosakata pujian, terutama di baris 25 Ange ou Sirène (Malaikat atau Putri Duyung), baris ke-26 fée aux yeux de velours (peri bermata beludru), dan baris ke-27 Ô mon unique reine! (O, wahai ratuku satu-satunya). Arti kata "satusatunya" menunjukkan bagaimana kecantikan adalah sesuatu yang berharga di mata penyair.

\section{Penyimpangan Makna}

Penyimpangan makna terjadi karena ambiguitas, kontradiksi, dan non-sense. Ambiguitas dapat terjadi pada kata, frasa, kalimat, maupun wacana yang disebabkan oleh munculnya penafsiran yang berbeda-beda menurut konteksnya. Kontradiksi muncul karena adanya penggunaan ironi, paradoks, dan antitesis.

\section{Ambiguitas}

Bahasa puisi itu bersifat banyak tafsir (polyinterpretable). Sifat banyak tafsir ini disebabkan oleh penggunaan metafora dan ambiguitas. Ambiguitas dapat berupa kata, frasa, klausa atau kalimat yang taksa atau mempunyai makna lebih dari satu. Untuk menciptakan misteri dalam sajak, untuk menarik perhatian dan selalu menimbulkan keingintahuan, ketaksaan itu membuatnya dapat ditafsirkan dengan bermacam-macam arti makna, sifatnya menjadi 'remang-remang' atau kabur.

Ambiguitas kecantikan disajikan sebagai misteri dari awal puisi, hal ini bisa dilihat dari baris 1-2 Viens-tu du ciel profond ou sors-tu de l'abîme, Ô Beauté ? (Apakah kau berasal dari langit jauh atau keluar dari jurang, O... kecantikan?). Keambiguan baris tersebut bisa dilihat dari keseluruhan makna baris puisi di atas.

Baris tersebut disajikan dalam bentuk kalimat interogatif termasuk pada beberapa bait dalam puisi tersebut, yaitu sors-tu du gouffre noir ou descendstu des astres? (Apakah kau keluar dari jurang hitam atau apakah kau turun dari bintang-bintang?) Kata-kata seperti profond (dalam), abîme (jurang), gouffre noir (jurang hitam), seperti merepresentasi dari kecantikan yang tampaknya selalu muncul dari hal-hal tak terduga.

\section{Kontradiksi}

Puisi menyatakan sesuatu dengan kebalikannya. Untuk menyatakan arti (makna) secara kebalikan itu dipergunakan gaya paradoks dan ironi. Paradoks merupakan gaya bahasa yang menyatakan sesuatu secara berlawanan atau bertentangan dalam wujud bentuknya. Kontradiksi dalam puisi Hymné À La Beauté ditunjukkan pada data berikut.

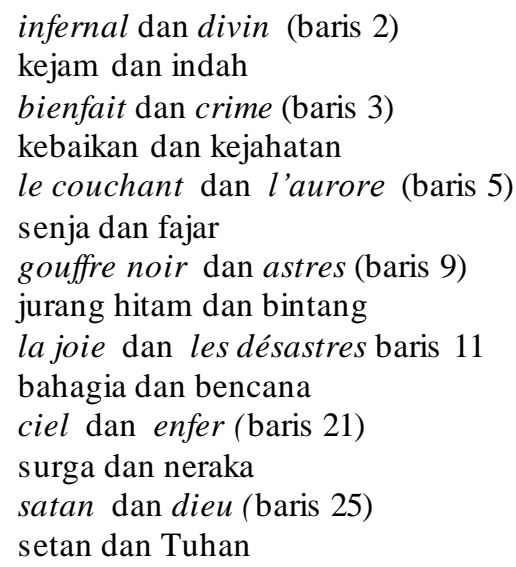

Data di atas menunjukkan adanya hubungan pertentangan dalam puisi. Hubungan pertentangan kata tersebut menekankan kepada baik dan jahat yang dihubungkan kata et (dan).

\section{Non-sense}

Non-sense adalah kata-kata yang secara linguistik tidak mempunyai arti sebab hanya berupa rangkaian bunyi, tidak terdapat dalam kamus. Meskipun tidak mempunyai arti secara linguistik, tetapi mempunyai makna (significance) dalam puisi karena konvensi puisi. Dalam puisi tersebut non-sense terlihat di beberapa baris pada bait, yaitu $\hat{O}$. Dalam hal ini $\hat{O}$ tidak memiliki makna apapun, hanya sekedar menampilkan kekaguman yang diikuti kata beauté (kecantikan) dan Ô mon unique reine! (O, wahai ratuku satu-satunya) yang terletak di baris 27 . 


\section{Penciptaan Makna}

Penciptaan makna merupakan konvensi kepuitisan yang berupa bentuk visual yang secara linguistik tidak mempunyai arti, tetapi menimbulkan makna dalam sajak (karya sastra). Jadi, penciptaan arti ini merupakan organisasi teks di luar linguistik. Penciptaan makna yang ditemukan dalam penelitian ini terdiri atas enjambement, rima, tipografi, dan homolog.

\section{Enjambement}

Dalam puisi, enjambement diartikan sebagai larik sambung, larik yang secara sintaksis melompat, bersambung ke larik berikut. Dengan kata lain, enjambement adalah lompatan kata atau frase pada akhir larik ke awal larik. Enjambement dapat di lihat pada bait berikut.

\footnotetext{
De Satan ou de Dieu, qu'importe? Ange ou Sirène,

Qu'importe, si tu rends, fée aux yeux de velours,

Rythme, parfum, lueur, ô mon unique reine! L'univers moins hideux et les instants moins lourds?

(Setan atau Tuhan, siapa peduli? Malaikat atau Putri Duyung, siapa peduli?

Jika kau kembali, peri bermata beludru,

Irama, parfum, cahaya, o.. wahai ratuku satu-satunya!

Semesta tak begitu buruk dan saat-saat tak begitu berat?)
}

\section{Rima}

Rima atau persajakan adalah perulangan bunyi yang sama dan teratur dalam puisi. Rima itu secara linguistik tidak memiliki arti, tetapi menimbulkan makna yang mendalam. Rima dapat menunjukkan perasaan senang, sedih, tertekan, menderita, kecewa, marah, dan lainnya. Dalam puisi Hymné À La Beauté karya Charles Baudelaire, kata yang ditulis pada baris pertama dan ketiga berbeda dengan baris kedua dan keempat, namun pengucapan kata pada baris pertama dan ketiga sama, sehingga termasuk dalam rima bersilang.

Viens-tu du ciel profond ou sors-tu de l'abîme, (1)

O Beauté? ton regard, infernal et divin, (2) Verse confusément le bienfait et le crime, (3) Et l'on peut pour cela te comparer au vin (4)
Apakah kau berasal dari langit (yang) jauh atau keluar dari jurang, (yang dalam) O... kecantikan? Tatapanmu, (amat tajam) kejam, dan (begitu) amat indah

(Ke) Bingung (antara) menumpahkan (sega-la) kebaikan dan kejahatan

Dan (semua) orang dapat membandingkannya pada (segelas) anggur

\section{Tipografi}

Tipografi merupakan tata huruf dalam sajak yang biasanya memiliki makna tersendiri. Dalam puisi Hymné À La Beauté digunakan tipografi sebagai beerikut. Pertama, terdapat tanda titik di setiap bait akhir puisi. Dimaksudkan untuk menegaskan bahwa menggambarkan rasa cinta yang begitu mendalam dengan perasaan atau nafsu yang membara. Kedua, semua bait sejajar, tidak ada yang lebih menjorok ke dalam. Dimaksudkan untuk menggambarkan bahwa semua rasa dan perasaan tertuang dalam puisi tersebut, memiliki rasa yang sama. Tidak ada yang menjadi utama.

\section{Homolog}

Homolog merupakan persejajaran bentuk atau persejajaran baris. Bentuk yang yang sejajar menimbulkan makna yang sama. Pada puisi Hymné À La Beauté terdapat kesejajaran baris dalam setiap baitnya serta terdapat kesejajaran bait dalam puisinya. Hal ini berarti, makna dan arti dari keseluruhan baris adalah sama atau setara. Tidak ada yang ingin ditonjolkan atau dilebihkan. Semua baris memiliki rasa yang sama. Perasaan yang digambarkan adalah perasaan cinta pada orang wanita yang digambarkan dengan rasa kasih sayang dan nafsu.

\section{Pembacaan He uris tik}

Pembacaan heuristik merupakan langkah untuk menemukan makna melalui pengkajian struktur bahasa dengan mengintrepetasikan teks sastra secara referensial lewat tanda-tanda linguistik. Langkah ini berasumsi bahwa bahasa bersifat referensial, artinya bahasa harus dihubungkan dengan hal-hal nyata. Dalam menerapkan pembacaan heuristik tidak menghiraukan kelengkapan atau kesempurnaan teks atau kondisi gramatikal sehingga apresiator dapat menambah ataupun mengurangi bentuk gramatikal yang ada guna menemukan makna yang terkandung dalam 
teks karya sastra itu sendiri. Berikut ini adalah contoh pembacaan heuristik puisi Hymne A la Beaute Karya Charles Baudelaire

Bait Pertama

Apakah kau berasal dari langit (yang) jauh atau keluar dari jurang, (yang dalam)

O... kecantikan? Tatapanmu, (amat tajam) kejam, dan (begitu) amat indah

(Ke) Bingung (antara) menumpahkan (sega-la) kebaikan dan kejahatan

Dan (semua) orang dapat membandingkannya pada (segelas) anggur

Bait Kedua

Kau (memandang dan) berada di (kedua) matamu (saat) senja dan (sinar) fajar

Kau semerbakan (wangi) parfum bagaikan malam (kelam) yang penuh badai

Ciumanmu adalah (sebotol) bir dan mulutmu adalah ampora

Yang membuat sang pahlawan (menjadi) lemah dan sang anak (nampak) gagah

\section{Bait Ketiga}

Apakah kau keluar dari jurang (yang) hitam atau apakah kau turun dari bintang?

Takdir (amat) terpesona mengikuti (untaian) rokmu bagaikan (seekor) anjing,

Kau menabur perangkap (antara) bahagia dan bencana,

Dan kau (telah) mengatur segalanya dan tidak menjawab apapun

\section{Bait Keempat}

Kau (telah) berjalan diatas kematian, kecantikan, kau (amat) tak peduli

Dari (kilauan) perhiasanmu, menjijikan, bukanlah (hal) yang paling menawan,

Dan (segala) pembunuhan diantara (kilauan) hiasan arlogimu yang sangat mahal, Diatas perutmu yang angkuh (telah) menari (di) penuh kasih sayang

Bait Kelima

(Seekor) Lalat (yang) sekilas terpesona (melihat) ke arahmu, (sebuah) lilin,

Kerlipan (cahaya), nyalakan, dan katakan: Berkati (lah) obor ini!

Sang kekasih (sambil) terengah-engah (dan) takluk pada cantiknya

Kedengarannya seperti orang (yang) sekarat (terlihat) membelai makamnya

\section{Bait Keenam}

Apakah kau datang (menghapiri) dari surga atau dari neraka, (entah) siapa (yang) peduli,
O.. kecantikan! (Seekor) Raksasa besar, (begitu) mengerikan, (dan) naif!

Jika (kedua) matamu, (garis) senyummu, (kedua) senyummu, terbuka untukku

Sebuah ketidakterbatasan (duniawi) yang aku cintai dan belum pernah ku kenal (sebelumnya)

\section{Bait Ketujuh}

(Antara) Setan atau Tuhan, siapa (yang) peduli? Malaikat atau Putri Duyung,

Siapa (yang) peduli? Jika kau (telah) kembali, peri bermata beludru,

(Sebuah) Irama, (bau) parfum, cahaya, o.. wahai ratuku (kau) satu-satunya!

Semesta (ini) tak begitu buruk dan saat-saat (ini) tak begitu berat?

Pembacaan heuristik merupakan langkah awal dalam pemaknaan puisi. Berdasarkan pembacaan awal tersebut di atas maka makna awal dari puisi ini adalah penggambaran tentang perempuan, kecantikan, dan segala sesuatu yang ada di sekitarnya, seperti munculnya diksi kata 'mata', 'surga', 'cinta' dan lainnya. Pembacaan heuristik adalah pembacaan puisi berdasarkan struktur bahasa (Lukmana, Pudjitriherwanti, dan Sunahrowi, 2017:2). Untuk memperjelas arti, bila perlu, pembaca memberi sisipan kata atau sinonim kata yang diletakkan dalam tanda kurung.. Begitu juga, struktur kalimatnya disesuaikan dengan kalimat baku (berdasarkan tata bahasa normatif) atau bila perlu susunan kalimatnya dibalik untuk memperjelas arti.

\section{Pembacaan Herme neutik}

Pembacaan hermeneutik adalah proses penguraian yang berangkat dari isi dan makna yang terlihat ke arah makna tersembunyi. Objek interpretasi dalam pengertian yang luas, dapat berupa simbol dalam mimpi atau bahkan mitosmitos dari simbol dalam masyarakat atau sastra. Berdasarkan analisis data, puisi Hymne A la Beaute menggambarkan rasa cinta dan sayangnya yang luar biasa penulis kepada kekasihnya. Penulis menggambarkan dan mendeskripsikan betapa cantiknya sang kekasih yang membuat penulis tergila-gila. Pembacaan hermeunetik puisi Hymne A la Beaute dipaparkan sebagai berikut.

Pada bait pertama, wanita dalam representasi pengarang digambarkan sebagai sesosok makhluk yang begitu istimewa karena digambarkan sebagai makhluk yang datang dari jauh. 
Kecantikannya yang mempesona setiap mata memandang begitu membuat siapa pun luluh pada pesonanya. Sosok tersebut bertindak sebagai pikiran dimana dihadapkan pada dilema baik dan buruk, bagaikan segelas anggur yang memabukan tetapi juga memberikan rasa senang.

Pada bait kedua, kecantikan wanita tersebut bagi pengarang diandaikan bagai menopang fajar dan senja, sejalan beriringan di sepanjang waktu. Bagai sepoi angin yang khas bagaikan parfum yang membuat siapa pun jatuh cinta pada sejuknya malam sehingga setiap orang begitu candu dengan harumnya dan jika tidak bisa menahan nafsunya maka akan menjadi lengah dan wanita tersebut akan merasa menang karena telah menguasai pikiran mereka.

Pada bait ketiga, sosok wanita yang begitu dikagumi datang dari tempat yang tak terduga, seakan takdir telah mengirimnya datang. Pengarang seolah terpikat pada pesonanya yang tidak hanya sekedar terlihat mengagumkan, tetapi juga membuat segalanya seperti anjing penurut pada majikannya. Bagaikan pisau bermata dua, di sisi lain dapat menjadikan tindakan yang dilakukan sesuai dengan akal sehat atau sebaliknya.

Pada bait keempat, kesombongan dari kecantikan si wanita bukanlah hal yang paling memikat, sekalipun kilauan-kilauan dari perhiasan mahal menghias tubuhnya, tetapi dia mempunyai seribu cara agar pesonanya membuat semua terpana.

Pada bait kelima, kecantikannya dapat memikat makhluk apapun, tutur katanya yang manis namun membunuh membuat para pemujanya takluk dan bertekuk lutut melakukan apa yang dia mau. Apapun yang dia mau dengan kecantikannya, dia akan mendapatkannya dari sang kekasih, pemujanya, rela melakukan apapun walau nyawa kekasihnya bagai diujung tanduk.

Pada bait keenam, tak ada yang peduli dari mana dia berasal, kecantikan yang begitu mengerikan tetapi juga memiliki sisi yang lugu. Pengarang mendeskripsikan wajah si wanita sedemikian rupa seolah si wanita direpresentasikan telah memberikan segalanya. Hasrat dan nafsu yang tak pernah dirasakan kini telah tergambar dan terlihat.

Pada bait ketujuh, pengarang menggambarkan dua sisi baik dan buruk yang sangat mencolok antara kekagumannya terhadap sosok wanita tersebut, meskipun begitu dia sangat mencintai dan menyayangi dengan sepenuh hati wanitanya dalam keadaan apapun. Pada titik yang lebih lanjut pembacaan hermenutik dimulai dengan langkah-langkah sebagai berikut: (1) mencari matriks, model, dan varian, dan (2) mencari hipogram (intertekstualisme).

\section{Matriks, Model, dan Varian}

\section{Matriks}

Matriks secara keseluruhan dalam puisi Hymné À La Beauté karya Charles Baudelaire adalah kekaguman pada kecantikan dan pemuja pesona dari kecantikan. Kata beauté merujuk pada pemujaan terhadap sebuah keindahan dan pesona terbesar dari seorang wanita yang di gambarkan oleh Baudelaire. Puisi tersebut adalah puisi romansa karena setiap baitnya menyajikan tentang cinta kasih dari seseorang yang begitu terpesona pada kekasihnya.

\section{Model}

Model yang ditonjolkan dalam beberapa baris dari bait puisi Hymné À La Beauté karya Charles Baudelaire adalah majas metafora. Metafora didefinisikan sebagai pemakaian kata atau kelompok kata bukan dengan arti yang sebenarnya, melainkan sebagai lukisan yang berdasarkan persamaan atau perbandingan. Bagian puisi yang bermajas metafora dipaparkan pada data berikut.

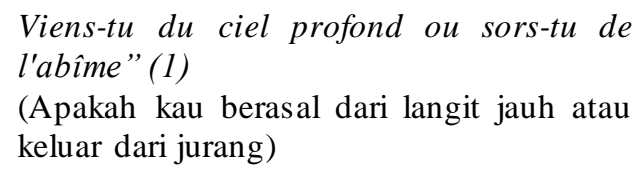

Pada baris pertama kata langit jauh (profond) dan jantung (l'abîme) merepresentasikan sesuatu yang tidak pernah dilihat sebelumnya, mengarah pada hal yang sangat membuat orang takjub akan suatu hal maka Baudelaire menggunakan diksi tersebut.

\section{Et l'on peut pour cela te comparer au vin" (4) \\ (Dan orang dapat membandingkannya pada anggur)}

Pada baris keempat Baudelaire menggunakan kata anggur (vin) karena baginya kecantikan merupakan sesuatu yang dapat membuat orang tak bisa lepas dari 'candu' yang memikat. Oleh karena itu, dapat dikatakan semua orang akan dibuat lupa tidak hanya dari segi fisik tetapi juga perasaan. 
Tes baisers sont un philtre et ta bouche une amphore" (7)

Ciumanmu adalah bir dan mulutmu adalah ampora" (7)

Pada baris ketuju kata amphora (amphore) yang berasal dari bahasa Yunani merupakan sejenis vas keramik dengan dua pegangan di bagian atas. Amphora sendiri juga menunjukkan sebagai simbol Dewi Athena.

Le Destin charmé suit tes jupons comme un chien" (10)

(Takdir terpesona mengikuti rokmu bagaikan anjing)

Pada baris kesepuluh kata anjing (chien) merujuk pada perilaku anjing yang sangat tunduk dan patuh pada pemilik atau tuannya. Baudelaire menggambarkan kecantikan sebagai representasi dari anjing karena siapa pun orang yang sedang dimabuk asmara oleh seseorang akan melakukan apa pun yang diminta oleh kekasihnya.

\footnotetext{
"Et le Meurtre, parmi tes plus chères breloques" (15)

(Dan pembunuhan di antara hiasan-hiasan arlojimu yang mahal)
}

Pada baris kelima belas, bagian arlojimu yang mahal (tes chères breloques) menunjukkan bahwa segala sesuatu yang tampak indah dan menawan mempunyai sisi kejahatan yang sangat dalam. Oleh karena itu, makna mewah dan mahal itu sendiri menunjukkan hal yang sangat rendah.

\section{Sur ton ventre orgueilleux danse amoureusement"(16) \\ (Diatas perutmu yang angkuh menari penuh kasih sayang)}

Pada baris keenam belas, bagian perutmu yang angkuh (ton ventre orgueilleux) digunakan Baudelaire untuk menggambarkan wanita sebagai Cleopatra. Cleopatra pada masanya adalah sebuah simbol dari kecantikan yang sangat dipuja baik laki-laki dan para wanita. Cleopatra berciri khas dengan selalu memakai aksesoris di atas perutnya, seperti tindik dari berlian atau emas. Hal itu menunjukkan tanda atau lambang kemolekan seorang wanita.

L'éphémère ébloui vole vers toi (17)

(Lalat sekilas terpesona ke arahmu)
Pada baris ketujuh belas puisi, kata lalat l'éphémère adalah representasi dari pemuja kecantikan wanita tak terkecuali Baudelaire, dia sangat mengagumi sosok wanita yang begitu anggun dan dia cintai, seperti dia tak bisa lepas dan ingin selalu mengikuti kemana pun wanita tersebut pergi.

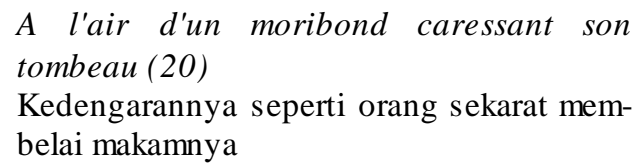

Pada baris keduapuluh, kata orang sekarat (maribond) melambangkan realita bagi mereka yang sedang dimabuk asmara. Mereka yang sedang jatuh cinta seolah-olah selalu memprioritaskan apa pun bagi pujaan hatinya. Baudelaire juga mengalami hal yang hampir sama ketika dia begitu memuja wanita yang sangat dicintainya, yaitu Jeanne Duval.

\section{De Satan ou de Dieu, qu'importe? Ange ou Sirène (25) \\ (Setan atau Tuhan, siapa peduli? Malaikat atau Putri Duyung)}

Pada baris ke-25, kata sirène direpresentasikan oleh Baudelaire. Siren atau yang lebih dikenal dengan putri duyung dalam mitologi Yunani adalah makhluk legendaris yang hidup di lautan. Mereka menyanyikan lagu-lagu yang memikat hati dan membuat para pelayar yang mendengarnya menjadi terbuai dan tergoda sehingga kapal mereka menabrak kapal dan tenggelam. Representasi Baudelaire ini mempunyai makna bahwa segala bentuk kecantikan pasti memiliki daya pikat tersendiri bagi siapa pun itu tanpa terkecuali.

\section{Varian}

Varian merupakan transformasi model pada setiap satuan tanda. Varian dalam puisi Hymné À La Beauté karya Charles Baudelaire diuraikan sebagai berikut.

Varian pertama adalah ungkapan Baudelaire tentang bagaimana pesona kecantikan wanita yang membuat setiap mata memandang pasti akan jatuh dalam pelukannya. Varian kedua adalah ungkapan Baudelaire tentang pemuja kecantikan yang begitu ingin melakukan apa pun bahkan sampai rela hampir membunuh dirinya sendiri. Model-model ditransformasikan ke dalam 
varian-varian, yakni pada baris yang menunjukkan adanya hubungan dengan memuja kecantikan seperti diuraikan pada data berikut ini

Et l'on peut pour cela te comparer au vin
(4)
(Dan orang dapat membandingkannya pada
anggur)

Tes baisers sont un philtre et ta bouche une amphore (7)

(Ciumanmu adalah bir dan mulutmu adalah ampora)

Le Destin charmé suit tes jupons comme un chien (10)

(Takdir terpesona mengikuti rokmu bagaikan anjing)

A l'air d'un moribond caressant son tombeau (20)

(Kedengarannya seperti orang sekarat membelai makamnya)

De Satan ou de Dieu, qu'importe? Ange ou Sirène (25)

(Setan atau Tuhan, siapa peduli? Malaikat atau Putri Duyung)

\section{Hipogram}

Hipogram adalah teks yang menjadi latar penciptaan teks lain atau yang menjadi latar penciptaan sajak yang lain. Sebuah sajak merupakan tanggapan terhadap teks atau sajak-sajak sebelumnya. Puisi Hymné À La Beauté ditulis dalam kumpulan sajak Les Fleurs du Mal. Corak puisi Baudelaire sering dirujuk sebagai romantisisme akhir yang masih bertutur lewat mitologi dan metafor klasik. Selain puisi Hymné À La Beauté terdapat puisi lain dari Baudelaire yang mengungkapkan hal yang sama, yaitu Le Fou et La Vénus. Sang wanita sama-sama diungkapkan dengan sebutan la muse, di mana dalam puisi $L a$ muse malade sang wanita mengalami sakit pada tubuhnya. Kedua puisi ini memiliki hubungan saling terkait karena Baudelaire sama-sama menggunakan tema yang sama untuk kedua puisi ini, yaitu kekaguman dan pesona pada kecantikan wanita. Dalam puisi Le Fou et La Vénus dapat dilihat bahwa Venus adalah salah satu dewi dalam mitologi Romawi. Dewi ini memiliki arti yaitu kecantikan, kesuburan, dan gairah.

Berikut adalah bait puisi berjudul Le Fou et la Vénus karya Charles Baudelaire yang berhipogram dengan puisi Hymné À La Beauté.

\section{Le Fou et la Vénus}

Cependant, dans cette jouissance universelle, j'ai aperçu un être affligé

Aux pieds d'une colossale Vénus, un de ces fous artificiels, un de ces bouffons, volontaires chargés de faire rire les rois quand le Remords ou l'Ennui les obsède, affublé d'un costume éclatant et ridicule, coiffé de cornes et de sonnettes, tout ramassé contre le piédestal, lève des yeux pleins de larmes vers l'immortelle Déesse.

Et ses yeux disent : - "Je suis le dernier et le plus solitaire des humains, privé d'amour et d'amitié, et bien inférieur en cela au plus imparfait des animaux.

Cependant je suis fait, moi aussi, pour comprendre et sentir l'immortelle Beauté! Ah ! Déesse ! ayez pitié de ma tristesse et de mon délire !"

Mais limplacable Vénus regarde au loin je ne sais quoi avec ses yeux de marbre.

\section{Si Gila dan Venus}

Namun, dalam kenikmatan duniawi ini, aku melihat yang berduka.

Di kaki Venus raksasa, salah satu dari orang bodoh membuat itu, salah satu dari orang-orang, sukarela menuntut raja-raja tertawa ketika penyesalan atau kebosanan terobsesi dengan mereka, mengenakan kostum yang brilian dan konyol, memakai tanduk dan lonceng, semuanya mengambil tumpuan, angkat mata penuh air mata, sampai ke Dewi Keabadian.

Dan matanya mengatakan:-"Aku adalah yang terakhir dan manusia paling kesepian, kehilangan cinta dan persahabatan, dan jauh lebih rendah daripada ini yang paling sempurna dari hewan.

Namun, aku membuat, aku juga, untuk memahami dan merasakan kecantikan abadi! Ah! Dewi! Kasihanilah kesedihanku dan igauanku!"

Tapi Venus yang tak kenal ampun terlihat jauh, aku tidak tahu ada apa dengan mata bulatnya. 


\section{Pembahasan}

Hasil analisis menunjukkan bahwa puisi Hymné À La Beauté memiliki ketidaklangsungan ekspresi, meliputi pergeseran makna, penyimpangan makna, dan penciptaan makna. Ketidaklangsungan ekspresi puisi itu merupakan salah satu cara yang digunakan penyair untuk menimbulkan kesan menyenangkan pada puisinya. Tujuan penyair menggunakan ketidaklangsungan ekspresi puisi adalah untuk menyembunyikan arti sesungguhnya untuk kemudian menjadi tantangan bagi pembaca.

Setiap penyair memiliki ciri khas atau gaya sendiri-sendiri dalam menggunakan ketidaklangsungan ekspresi dalam puisinya. Tujuan penyair menggunakan ketidaklangsungan ekspresi puisi adalah untuk menyembunyikan arti sesungguhnya. Dengan kata lain, ketidaklangsungan ekspresi dalam pemahaman Riffattere adalah terciptanya makna baru sesudah dirusak dan diganti.

Analisis dengan menggunakan pembacaan heuristik dan hermeneutik dalam kerangka teori semiotika Riffaterre telah menemukan beberapa hal yang sangat prinsip dalam analisis dan pengungkapan makna puisi; antara lain berkaitan dengan tema utama yang terangkum dalam matriks puisi, model dan variasi pengungkapan dalam puisi karya Baudelaire, dan hipogram dengan karya sebelumnya. Pengembagan teori ini melalui aplikasi terhadap objek material ini akan semakin memperkaya kajian dalam analisis puisi dan sekaligus memiliki implikasi logis pada kajian-kajian yang akan dilakukan selanjutnya, utamanya pada puisi.

Teori semiotik Riffaterre membawa kebaruan dikarenakan dua gagasan aksiomanya yang mempertimbangkan ketidaklangsungan ekspresi puisi dan kesatuan makna. Cara kerja teori yang mendasarkan pada dua level pembacaan menemukan kelengkapan teoritik untuk mendapatkan pemahaman dan pemaknaan yang komprehensif dari puisi karena level heuristik berpijak pada struktur, mimetik (arti kamus, bercirikan hubungan oposisional, makna yang belum memusat) dan level retroaktif atau hermeneutik berpijak pada pencarian unsur-unsur pembentuk teks puisi untuk mendapatkan kesatuan makna, semantik (model, matrik, hipogram).

Analisis semiotik merupakan analisis yang digunakan untuk memahami makna yang terkandung di dalam teks karya sastra, khususnya puisi. Hal ini dilakukan karena bahasa puisi bersifat padat dan ringkas. Oleh karena itu, perlu adanya sebuah teori atau kajian yang menelaah bahasa puisi secara terperinci dan mendalam sebagaimana ditunjukkan dalam kajian ini. Puisi merupakan ekspresi tidak langsung dari jiwa pengarang. Dalam menganalisis tanda dalam puisi diawali dengan menganalisis ketidaklangsungan ekspresi dalam puisi, meliputi pergeseran makna, penyimpangan makna, dan penciptaan makna. Analisis ini digunakan untuk memahami gaya, diksi, dan bentuk puisi. Selain itu juga untuk memperkuat pemaknaan puisi secara keseluruhan.

\section{SIMPULAN}

Puisi Hymné À La Beauté karya Charles Baudelaire menyajikan bentuk puisi yang indah dan penuh dengan metafora. Untuk memahami karya tersebut diperlukan pembacaan berulangulang, pemaknaan, dan penafsiran secara baik dan mendalam. Dalam puisi tersebut, Baudelaire mengungkapkan sebuah romansa. Romansa yaitu luapan rasa cinta seseorang terhadap sang kekasih. Romansa yang tertuang dalam puisi Hymné À La Beauté karya Charles Baudelaire ini merupakan ungkapan untuk Jeanne Duval, wanita yang sangat dicintai Baudelaire. Penggambaran Baudelaire atas ungkapan cintanya kepada Jeanne sangat tercermin dari puisi ini. Bait demi bait yang ditata dengan diksi yang menarik dan tajam menunjukkan bahwa rasa cinta yang begitu dalam terhadap kekasihnya. Rasa cinta itu diungkapkan melalui ketidaklangsungan makna.

\section{UCAPAN TERIMA KASIH}

Penulis menyampaikan ucapan terima kasih kepada mitra bestari (reviewers) yang telah memberikan saran, kritik, dan rekomendasi perbaikan artikel ini.

\section{DAFTAR PUSTAKA}

Baudelaire, C. 1857. Les Fleurs du Mal. Paris: Auguste Poulet-Malassis
Lukmana, Sem. D., Anastasia Pudjitriherwanti, and Sunahrowi. 2017. La Religiosite et l'Obsession dans l'Anthologie de la Poesie les Fleurs du 
Mal Travail de Charles Baudelaire: l'Etude de la Semiotique de Riffaterre. Journal of Lingua Litteratia, 4(1): 1-8.

Matalu, N. H. V., Suluh Edhi Wibowo, and Sunahrowi. 2017. Les Cinq Poèmes de Charles Baudelaire Choisies de l'Anthologie "les Fleurs du Mal": Une Étude Selon la Perspective Hermèneutique Phénoménologique de Paul Ricœur. Journal of Lingua Litteratia, 4 (1): 14-22.
Riffaterre, M. 1978. Semiotic of Poetry. California: Indiana University Press.

Sugiyono. 2005. Metode Penelitian Administrasi. Bandung: Alfabeta.

Teeuw, A. 1984. Sastra dan Ilmu Sastra: Pengantar Teori Sastra. Jakarta: Dunia Pustaka Jaya.

Whitney, F. L.1960. The Elements of Resert Asian Eds. Osaka: Overseas Book Co. 